Table 1. (Ref. 3.) LaYoUt, $5 \times 5$ BaLanCed Lattice SQdaRe;

\begin{tabular}{|c|c|c|c|c|c|}
\hline \multirow{2}{*}{ Variety } & \multicolumn{3}{|c|}{ Mean yield $(\mathrm{lb}, / \mathrm{acre})$} & \multirow{2}{*}{$\begin{array}{c}\text { Variety } \\
\text { mean }\end{array}$} & \multirow{2}{*}{$\begin{array}{l}\text { Percent- } \\
\text { age (cf. } \\
\text { Siam 29) }\end{array}$} \\
\hline & 1955 & 1956 & 1957 & & \\
\hline Siam $E \cdot R .25$ & 4,016 & 3,373 & 3,385 & 3,591 & $121 \cdot 9$ \\
\hline$" \quad 16$ & 4,060 & 3,266 & 3,314 & 3,647 & $120 \cdot 4$ \\
\hline $\begin{array}{ll}06 \\
y\end{array}$ & $\begin{array}{l}3,8,26 \\
3,893\end{array}$ & $\begin{array}{l}8,300 \\
3,147\end{array}$ & $\begin{array}{l}3,284 \\
3,218\end{array}$ & $\begin{array}{l}3,422 \\
3,419\end{array}$ & $\begin{array}{l}116 \cdot 1 \\
110 \cdot 0\end{array}$ \\
\hline$\Rightarrow \quad 69$ & 3,679 & 3,226 & 3,222 & 3,376 & $114 \cdot 6$ \\
\hline$\Rightarrow 59$ & 3,548 & 3,401 & 3,127 & 3,359 & 114.0 \\
\hline " 6 & 3,544 & 3,214 & 3,294 & 3,351 & $113 \cdot 8$ \\
\hline 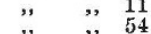 & $\begin{array}{l}3,695 \\
3,925\end{array}$ & $\begin{array}{l}3,214 \\
3,226\end{array}$ & $\begin{array}{l}3,119 \\
2,845\end{array}$ & $\begin{array}{l}3,343 \\
3,332 \\
\end{array}$ & $\begin{array}{l}113 \cdot 4 \\
113 \cdot 1\end{array}$ \\
\hline$\Rightarrow \quad 24$ & 3,544 & $\begin{array}{l}3,044 \\
3,040\end{array}$ & $\begin{array}{l}2,845 \\
3,286\end{array}$ & $\begin{array}{l}3,382 \\
3,291\end{array}$ & $111 \cdot 7$ \\
\hline , 71 & 3,599 & 3,294 & 2,913 & 3,269 & 110.9 \\
\hline , 48 & 3,512 & 3,016 & 3,064 & 3,197 & $108 \cdot 5$ \\
\hline$", 20$ & 3,702 & 3,056 & 2,802 & 3,187 & $108 \cdot 1$ \\
\hline , 46 & 3,726 & 3,016 & 2,754 & 3,165 & $107 \cdot 4$ \\
\hline,$\quad 10$ & 3,580 & 3,135 & 2,800 & 3,165 & $107 \cdot 4$ \\
\hline , 18 & $\begin{array}{l}3,564 \\
3149\end{array}$ & 2,857 & $\begin{array}{l}3,004 \\
0\end{array}$ & 3,142 & $106 \cdot 6$ \\
\hline 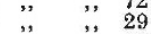 & $\begin{array}{l}3,202 \\
3,202\end{array}$ & 3,000 & $\begin{array}{l}2,929 \\
2968\end{array}$ & $\begin{array}{l}3,130 \\
3,057\end{array}$ & $\begin{array}{l}106 \cdot 0 \\
103 \cdot 7\end{array}$ \\
\hline ," 42 & $\begin{array}{l}0,02 \\
3,353\end{array}$ & $\begin{array}{l}3,790 \\
2,790\end{array}$ & 2,9 & $\begin{array}{l}3,00 \% \\
3,030\end{array}$ & \\
\hline " & $\begin{array}{l}0,016 \\
3,016\end{array}$ & 3,123 & 2,8 & $\begin{array}{l}3,011 \\
3,011\end{array}$ & 102.0 \\
\hline \multirow{3}{*}{$\begin{array}{l}\text { Siam } 29 \\
\text { (Control) } \\
\text { Siam } E . R .73\end{array}$} & 3,254 & 2,671 & 3,008 & 2,978 & 101.1 \\
\hline & 3,417 & 2,738 & 2,687 & 2,947 & \\
\hline & 3,361 & 2,7 & & 2,931 & 99.5 \\
\hline , 70 & 2,806 & 2,964 & 2,952 & 2,907 & $98 \cdot 6$ \\
\hline $\begin{array}{l}\text { Season mean } \\
\text { S.E. } 1 \mathrm{~b} . / \mathrm{ac} \text {. }\end{array}$ & $\begin{array}{l}3,528 \\
\pm 234\end{array}$ & $\begin{array}{l}3,091 \\
\pm 186\end{array}$ & $\begin{array}{l}3,012 \\
\pm 131\end{array}$ & $\begin{array}{r}3,210 \\
\pm 109\end{array}$ & \\
\hline
\end{tabular}

S.E. seasons $\pm 38 \mathrm{lb}$./acre; S.E. interaction $\pm 115 \mathrm{lb}$./acre

as in the above, would indicate that established improved strains are either not totally homozygous or that there is an accumulation of mutations which affected yield.

I acknowledge with thanks the kind permission of the Public Services Commission, Federation of Malaya, to publish this communication.

Division of Botany,

Department of Agriculture, Kuala Lumpur,

Federation of Malaya.

${ }^{2}$ Ghose, R. L. M., and Daiya, L. R., International Rice Commission Paper IRC/BP/52/15 (1952).

${ }^{2}$ Brown, F. B., Malayan Agric. J., 40, 4 (1957).

${ }^{8}$ Brown, F. B., Sci. Bull. 100, Dept. of Agric. (1959).

\section{Selfing of Self-Incompatible Cocoa}

The Upper Amazon cocoa varieties, of great importance to the breeder, are all self-incompatible so that it is difficult to obtain valuable alleles in the homozygous condition. The incompatibility mechanism operates through failure of fusion of male and female gametes carrying the same dominant allele, followed by the loss of the whole ovary even though normal fusion has occurred in other ovules.

Attermpts have been made to self a self-incompatible clone ('Nanay 32') by applying a quantity of pollen from a tree compatible with it together with a little of the pollen of the clone itself. The tree used to provide the compatible pollen is hornozygous for a marker-gene detectable in the seedlings ('axil spot'). Out of some dozen attempts, one pod was obtained which gave 46 seedlings showing the 'axil spot' character and 4 without it. These four seedlings are thought to be selfed progeny of the clone.

The theory behind the attempt was that if the proportion of ovules in which dominant alleles were combined were sufficiently low the flower may remain on the tree and selfed ovules in which different alleles, or alleles recossive to others present, had come together could develop into seed. 'Nanay 32' has the alleles 2 and 4 on Knight and Rogers's terminology ${ }^{2}$, allele 2 being dominant to allele 4 . These four seedlings will thus be $2 \cdot 4$ or $4 \cdot 4$, any ovules which were $2 \cdot 2$ having failed.

Posnette ${ }^{3}$, who demonstrated that pods could be set on a self-incompatiblo treo when both its own pollen and pollen from a self-compatible tree were applied to the same flower, suggested a similar method for determining if any of the seeds resulted from self-fertilization. $\mathrm{He}$ suggested pollinating a selfincompatible white-beaned tree with both its own pollen and pollen from a compatible tree homozygous for purple-boan, when any white beans obtained would result from self-pollination as the purple-bean characteristic is dominant. Van der Knaap applied pollen from a compatible white-seeded tree to a selfincompatible tree heterozygous for purple and white beans together with its own pollen, and obtained an indication that some selfing was taking place from the lower proportions of white beans in the progenies than whon the tree was only crossed. The present work is believed to be the first actually carried out in which it is possible to pick out the selfed seedlings.

West African Cocoa Research Institute,

$$
\text { D. R. Glendinning }
$$

$$
\begin{aligned}
& \text { P.O. Box No. 8, } \\
& \text { Tafo, }
\end{aligned}
$$

$$
\text { Ghana. }
$$

${ }^{1}$ Cope, F., Nature, 181, 279 (1958).

${ }^{2}$ Knight, Ronald, and Rogers, H. H., Heredity, 9, 1, 69 (1955),

${ }^{3}$ Posnette, A. F., Trop. Agric., 17, 67 (1940).

"Van der Knaap, W. P., Rep. Fourteenth Intern. Hort. Cong., 2, 1287 (1955).

\section{Occurrence of a Brown Mutation in the Syrian Hamster}

Cinnamon or 'brown' mutations in species of rodents are well-known modifications of the pigmentary physiology of the wild agouti colour. A comparable mutation is now recorded for the Syrian hamster, Mesocricetus auratus, one of the compara. tively recent additions to the range of laboratory rodents. The mutant allele is inherited as a recessive to the normal gene and the genetic symbol $b$ is proposed for its designation.

In the cinnamon hamster all the eumelanic pigmentation, which is normally black in the wild type, is now changed to brown. The overall effect is a cinnamon-orange of a particularly rich colour. This is due to the fact that the wild agouti Syrian hamster is considerably more auburn than the drab agouti of, say, the mouse or rabbit. The agouti brown mouse or rabbit is much brighter than the black agouti, and this brightening effect is greatly enhanced in the hamster, as $a_{1}$ consequence of the initial auric pig. mentation. The auburn colour is duo to abundant phromelanin, which is possibly only indirectly affected by the brown mutation. The simplest assumption at present is that the brightening is duo to an optical effect ; although it is also possible that the modification of black eumelanin to brown could so shift the pigmentary processes that additional phæomelanin is formed out of the chromogenic substrate.

The colour of the cinnamon hamster is a rich cinnamon-orange. The black flashes of the wild type are replaced by brown, as are also the black tips of the coat hairs and the shafts of the vibrisse. The 